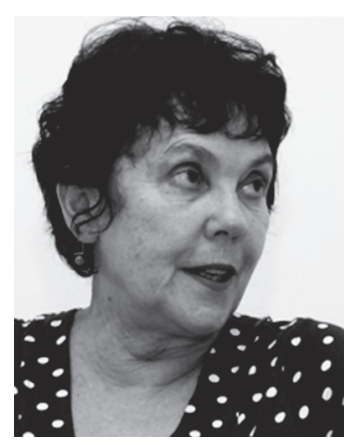

\title{
Fúlvia Maria de Barros Mott Rosemberg
}

Formada em Psicologia pela Universidade de São Paulo (USP) em 1965 e doutorada em Psychobiologie de l'Enfant - Ecole Pratique des Hautes Etudes /Université de Paris, em 1969, Fúlvia Maria de Barros Mott Rosemberg foi pesquisadora consultora da Fundação Carlos Chagas (FCC) e professora titular da Pontifícia Universidade Católica de São Paulo (PUC-SP), onde coordenava o Negri (Núcleo de Estudos de gênero, raça e idade).

Durante várias décadas, Fúlvia desenvolveu estudos sobre Ideologia e Educação, consolidando uma trajetória profissional que muito ampliou a contribuição da Psicologia para a compreensão das relações raciais e de gênero no Brasil, no campo da educação infantil. Atuou com ênfase em Psicologia Social e Estudos Sociais da Infância, principalmente, nos seguintes temas: relações raciais, relações de gênero, relações de idade, ação afirmativa, educação e educação infantil. Entre as publicações de Rosemberg destacam-se "A Educação da Mulher" (1985), "Canil da Nona" (1987)" e Creches e Pré-escolas no Hemisfério Norte (1998)".

Em várias entrevistas e publicações sobre relações raciais, Fúlvia de Rosemberg rechaçava o entendimento do termo "cotas" para a discussão das medidas tomadas para inserção de excluídos em diversos âmbitos da sociedade, como a universidade. Ao querer corrigir o rumo dos questionamentos, Fúlvia sempre introduzia a expressão "ações afirmativas", que engloba um conjunto de mecanismos, inclusive o das próprias cotas raciais. Segundo a pesquisadora, as cotas sociais (por renda) não são suficientes em uma sociedade como a brasileira em que, argumentava, o racismo é "institucional".

Em sua trajetória docente, Fúlvia Rosemberg orientou 42 dissertações de mestrado e 16 teses de doutorado, além de participar de uma centena de bancas de mestrados e doutorados. Também atuou profissionalmente na Organização das Nações Unidas para a Educação, Ciência e Cultura (UNESCO), Instituto da Educação de Hamburgo (UNESCO, Alemanha), Instituto Sedes Sapientiae (SEDES).

Fulvia faleceu em setembro deste ano, quando esta Revista já a tinha escolhido como a homenageada desta edição, uma vez que pretendemos que os nossos escolhidos recebam as suas homenagens, porém não houve tempo para tal dado ao seu falecimento em 12 de setembro passado, e deixa importante legado para a Psicologia brasileira. 